\title{
THE FUTURE OF PERSIA
}

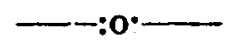

IT is easy to underrate the importance of Persia. The Persian Mohammedan is weak and unstable; the population of the country is not much more than ten millions ; and the greater part of the area is desert. So most of those interested in the awakening of the Fastern nations leave Persia, as an active force, entirely out of their reckoning.

But Persia is a land of latent resources. The people have great capacities, and their character is peculiarly susceptible to alteration by religious influence. Those who cling to Zoroastrianism are very different from the Mohammedans ; yet, if converted, they lose in a generation or two all their former characteristics. The early Babi movement turned the Persian townsman, a most unmilitary person, into a brave and courageous soldier. Behaiism, as well as the earlier Babiism, has produced thousands of willing martyrs; and if it has not made the Behai more truthful, honest and reliable than he was before, this is due to elements in the religion itself. Christian converts certainly develop these qualities, sometimes in a very marked degree.

The potentialities of the soil are as great as those of the people. At present almost all the population is settled somewhat thickly in restricted areas, where water can be brought to the surface by primitive methods. This concentration of the population in island towns and villages, separated by seas of uninhabited desert, affords peculiar facilities for successful missionary work. But the proportion of sea to island is likely to change as greatly in the future as it has done in the past. The Parsees declare that immediately after the Mohammedan conquest the son of the Zoroastrian Shah went to considerable trouble to shew the Khaliff Omar that there 
was then no place in all the country which was out of sight of villages and cultivation, but that the continuance of this state of things would depend on the care and good government of the new rulers. This statement of the condition of Persia must have been an exaggeration; as is also the epigrammatic summary of a modern writer that Persia consists of $i$ wo parts, the salt desert and the desert which is not salt. But the fact that the deserts have vastly increased in area can be demonstrated. The places where Alexander the Great brought great armies and fed them would now be incapable of yielding a hundredth part of the necessary forage. Tanks, too, that have been built for the reception of rain water can be found on the summits of barren hills, where rain no longer falls. The country has suffered greatly by foreign invasion ; but most of its present unproductiveness is the result of bad management. Instead of careful afforestation to attract and husband rainfall, the few remaining trees in the dry districts are being sacrificed for charcoal. Much could be done by means of artesian wells and by engineering. But there is no Government capable of making, or even of encouraging, the necessary efforts. The agricultural resources, as well as the mineral, are undeveloped. But if a stable Government faces the essential problems and produces some security of tenure for property owners, the population of Persia should increase by leaps and bounds. A temperate climate, a soil of surpassing fertility, specially suited to the growing of fruit as well as grain, and a huge undeveloped mineral wealth, these are assets not to be despised.

We cannot predict the future; but nobody can help expecting certain great changes in Persia. In the North, immigration from Russia; in the South, Indians and Arabs flocking to the oil-fields; the Shah ruling over a country of growing wealth, population and importance ; the neighbouring powers acquiring daily an increased interest in the development of the central plateau as a food exporting area; and with it all, the decay of the Ottoman Empire, leaving Persia nearly, if not quite, the greatest of the remaining Mohammedan independ- 
encies : these are the things that seem inevitable, unless indeed we are on the eve of some great change in the dispensation of God's sovereignty that wili set all political forecasts at naught.

If such things happen, Persia will reach a point of wealth and development such as she has not seen for centuries. And yet the Shah will find himself curbed by his stronger neighbours on points of foreign policy. The country will want to take an adequate and worthy part in the Renaissance of the East, but will find herself unable to do so, unless she sets aside imperial and military ideals for aspirations of a very different nature.

This will be no new idea in Persia, a country which seems, ever since the Mohammedan conquest, to have used most of her versatility and determination to secure a position of leadership, or in default of that, of peculiar independence in all that relates to religious thought. Persia has never been satisfied with an ordinary position in the Mohammedan world. The first cause of dissatisfaction was perhaps principally racial.

The Aryan Persians had accepted Mohammed and Islam, but they were unwilling to accept the ecclesiastical domination of Semitic Arab Khalifs, who lived far away, had no knowledge of their peculiar needs, and had no prophetic power to enable them to modify or adapt the already stereotyped revelation, or the traditions that were fast hardening into something as unalterable as the Koran itself. Persia, therefore, accepted the doctrine of the Imamate, whereby Mohammed became for them the first of a hierarchic and prophetic dynasty, the members of which were all equally appointed by God. So for a long period the Persian Shiahs had the advantage of a personal Head, who, although he produced no new book of revelation, possessed a prophet's powers of adaptation and leadership. After the occultation, or departure into hiding, of the twelfth and last Imam, the four who in turn claimed to be in communication with the Imam must have held far greater discretionary powers than any Sunni Khalif. Even since this period (for the fourth of these refused to name a successor), the continuance among the Shiahs of the high order of Mujtabids, 
who can pronounce on most points of the religion, has always given to Persian Mohammedans a latitude of views unknown to the Sunni sect. For the Sunnis have never allowed to their popularly appointed Khalifs any share in prophethood; they have killed off their mujtabids in the early centuries of the Dispensation, and have petrified all authoritative pronouncements on moot points in the written Sunnat.

Whether the Shiah movement was an unsuccessful bid for leadership on the part of Persia, or whether it was a successful assertion of Aryan independence of thought, it is difficult to say. It was probably in large measure the result of the peculiar temperament of the Persian, who has a warm enthusiasm for a personal leader, and under the inspiration of such leadership shews great missionary zeal. But he has little of the spirit that makes men tenacious of the essentials of their creed, and would rather adapt the creed to suit the circumstances of time and place. Yet in the theory of the Imamate there was no real rejection of the doctrines of Mohammed : this cannot be said for the Sufi heresy, in which the Persian gave his powers of adaptation far freer scope. The occasion of Sufiism was the contact of the Moslem with the Hindu Pantheist. Islam rests on the assumption that God is God and man is man and that the indwelling of God in man is an impossibility. Hinduism goes to the opposite extremity, and makes everything a part of deity. Sufiism was no attempt to convert the Mohammedan world ; it was the development of a philosophy adapted from the best thoughts of Hinduism, and set in terms of Islam for the benefit of those who had cast off the essential teaching of Mohammed. The Sufi saint claimed the possession of God's Spirit, and declared himself divine. The literature of the Sufi poets touched the heart of Persia. It made a new rallying point for the people's patriotism. It exalted the national literature and language to a rank only second to that of the Koran in the Moslem.

The close touch between Persia and the West dates from the Napoleonic period, and has brought forth an adoption of Moslem thought more extraordinary than 
Sufiism. The Persian desired to meet the Christian on friendly and equal terms, and also to develop his own life and actions on lines more suited to modern times. The first part of the movement was revolutionary, aiming at the immediate adaptation of the people as a whole to their new circumstances. The later Behaiism employs peaceful and gradual methods, and includes a missionary propaganda. The earlier movement might have fitted a Moslem nation for contact with the West; the later movement seeks to join East and West under one banner, and has succeeded in gaining many converts in America and France, and some in other European countries. Behaiism is a compromise. The prophet is an incarnation of the deity, but his followers cannot experience the indwelling of God. As Christ was superseded by Mohammed, so Mohammed has been superseded by the Behau 'llab, whose book borrows many of the ethical commandments of the Gospel, which Mohammed deliberately set aside. So there is a denial of the perpetuity or growth of the moral law, a concession to Islam which outbalances the more superficial similarities to Christianity. Behaiism has failed both in the formation of character and in the improvement of the country by promoting good government. But it has been widely accepted in Persia and has made its way to Egypt. It has had some success in uniting the loose pseudo-Christian thought of the West with the equally loose Mohammedanism that has succeeded Sufiism in Eastern by-ways; and it has enabled the Eastern Mohammedan and Western Christian to meet one another on an easier footing.

These three movements shew that Persia has long desired to undertake religious leadership, and has refused the restrictions of Mohammedanism, especially when imposed upon her by foreigners. If she finds herself wealthy and prominent, she may turn for a time to thoughts of Empire. But if such aspirations are checked, it is at least probable that she will reassume the more peaceful rôle.

Then if Behaiism fails to serve her purpose, she will hardly scruple to break further still away from Islam. We can hardly hope that a determination for national 
aggrandisement or a desire to solve a social and commercial problem will become a spiritual seeking after truth. But just as earthly aspirations in other countries have been used by God for the creation of opportunities for spiritual work and spiritual religion, so it may prove in Persia, and through Persia in the whole of the ancient Mohammedan world.

Persia seems to have found it peculiarly difficult to reconcile the history of the present war with the belief that Europeans have understood the Gospel of Christ. This may prove not a stumbling block, but an incentive to her to study the Gospel more carefully herself. One cannot help fearing that a study so undertaken would be subject to great dangers, and might lead to serious heresy, but it might nevertheless do great good. We want wise missionary work during the next few years. There must be careful discrimination between what is essential and what is added or shaped by national thought and custom. There must be real trust in the guiding Spirit of God. God has used many instruments in building up His Church. Some of the churches of past ages seem to have soon lapsed into heresy, and after a while vanished from human ken. Yet it may be that they were not altogether failures, and that the characteristics, which made them as congregations unstable and shortlived, made some of their members fit for a peculiar part in the building up of the whole Catholic edifice. If a wide Christian movement arises in Persia, the Bishops may have great anxiety; but few things would conduce more to the downfall of Islam and the triumph of Christ's Cross throughout the East. Persia is no unimportant country. It is perhaps the only place where the East and the West can meet. The Persian is a white man, bubbling over with humour, full of ideas, and yet an Eastern to the core. $\mathrm{He}$ is already struggling with a religion that has become impossible for him; and if he can be induced to turn to Christ as his Helper, then he may prove the evangelist for whom the Mohammedan world has been waiting.

Napier Malcolm. 